Printed in Great Britain

\title{
A SCANNING ELECTRON MICROSCOPE STUDY OF NOTUM STRUCTURES IN SOME DORID NUDIBRANCHS (GASTROPODA: OPISTHOBRANCHIA)
}

\author{
ANNETRUDI KRESS \\ Department of Anatomy, University of Basle, Switzerland
}

(Figs. 1-6)

\begin{abstract}
Skin structures of nine different species of dorid nudibranchs were examined at the scanning electron microscope and the light microscope levels. From these observations the animals are grouped into three categories.

1. Dorids with spicule-supported tubercles carrying a sensory knob (Rostanga rubra, Forunna tomentosa, Onchidoris sparsa, Onchidoris pusilla).

2. Dorids with small sensory papillae set in pits and distributed randomly between projecting spicules (Aegires punctilucens).

3. Dorids with tubercles differing in shape from one species to another, invested with numerous spicules but without conspicuous sensory structures. The tips of the tubercles do, however, contain single sensory epithelium cells (Archidoris pseudoargus, Acanthodoris pilosa, Onchidoris muricata, Onchidoris bilamellata).
\end{abstract}

\section{INTRODUCTION}

Notable among the external anatomical features of the dorids are the tubercles of varying number, size and shape, covering the notum (e.g. Alder \& Hancock, 1845-55; Thompson \& Brown, 1976). These tubercles are mostly supported by calcareous spicules which lie in great numbers within the integument. Labbé $(1929,1933)$ gave a detailed description of these structures, in particular those of Rostanga rubra and forunna tomentosa, revealing that these tubercles have distinct sensory qualities. Very little is known about the notal skin and possible sensory structures in other dorids (Hoffmann, 1932-34). The purpose of this study is to investigate these frequently minute tubercles of the dorid skin in several species on the basis of scanning microscope and light microscope examination.

\section{MATERIAL AND METHODS}

The main problem consisted in preventing extensive mucus secretion and contraction of the animal, both of which take place immediately upon handling the animal. A fast-working fixative with good preservation qualities for structural details was needed.

A second problem arose during dehydration. The innumerable calcareous spicules (Fig. 1) lying randomly orientated within the integument created serious cracks and distortion of the skin. These two facts made it necessary to try a great number of techniques. Two or more specimens of each species were available to test different methods of preparation for the SEM and for light microscopical sections.

The best results were obtained by having the animal moving normally on a piece of rock or algae, then 'flooding' it with the fixative, $40 \%$ neutral formalin followed by $5 \%$ neutral formalin about $10 \mathrm{~min}$ later, where a longer fixation period is desirable. Dehydration with ethanol followed by amylacetate produced better results than acetone.

In an attempt to remove excessive mucus, a $0.1 \%$ Pronase solution was used before fixing. The method recommended by Mariscal (1974) for sensory surfaces of sea-anemones did not prove successful.

0025-3154/81/2828-1329 $\$ 1.50$ (C) 1981 Mar. Biol. Ass. U.K. 
Critical point drying gave far better results than ordinary air drying.

The same method applied to several specimens could give different results. Freshly collected animals gave better pictures than those which had been kept in tanks with circulating seawater where particles of debris had accumulated between the tubercles and adhered to the abundant secreted mucus.

The specimens were sputtered with gold applied in an ionized argon atmosphere and examined in a Joel P 15 scanning microscope. For light microscopy the fixatives were formalin, Halmi or Helly. Serial sections of 5 and $7 \mu \mathrm{m}$ thickness were cut, and embedded in paraffin wax. The preparations were stained with haematoxylin-eosin, azan, Prenant and Gomori (silver impregnation).

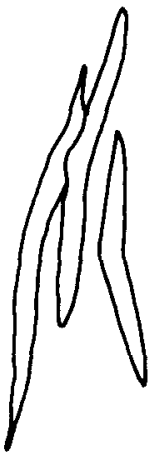

a

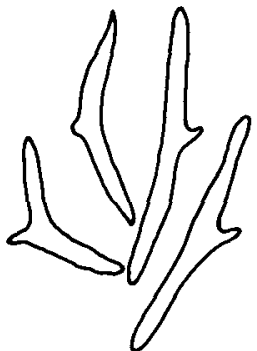

b

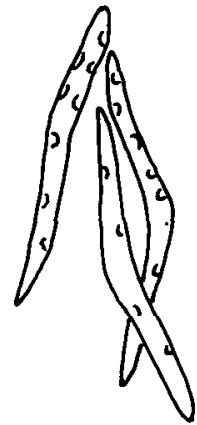

c

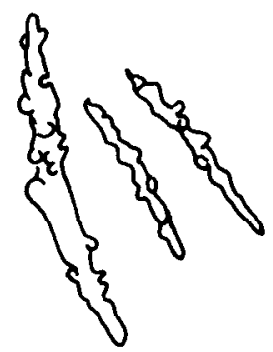

d

Fig. 1. Spicules as found in the skin of different dorid species (according to Alder \& Hancock, 1845-55). (a) Onchidoris muricata (very similar are Onchidoris pusilla, Rostanga rubra and forunna tomentosa); (b) Onchidoris bilamellata. (c) Archidoris pseudoargus. (d) Acanthodoris pilosa.

\section{OBSERVATIONS}

1. Dorids with spicule-supported tubercles carrying a sensory knob.

Rostanga rubra (Risso, 1818)

\section{Macroscopical appearance}

The mantle bears densely packed small spiculose tubercles of somewhat uniform size, making the animal rough to the touch (Fig. $2 \mathrm{~A}$ ).

\section{$S E M$}

The tubercles stand tightly packed, and are about $300-400 \mu \mathrm{m}$ high (Fig. $2 \mathrm{~B}$ ). They look like a calyx or a half-shut umbrella, the point of which is located in the connective tissue of the mantle. The tubercles are strengthened by 4-6 long divergent spicules spaced at regular intervals. In the central area of the tubercles a longish knob of about $80 \mu \mathrm{m}$ in diameter protrudes, bearing a tuft of long cilia at the top. Along the margin of the calyx as well as down the lateral surface of the calyx and the knob, cilia-bearing cells can be seen at regular intervals (Fig. 2 C, D).

Fig. 2. (All Rostanga rubra.) (A) Whole animal, $10 \mathrm{~mm}$ in length. Note the rough notum structure. (B) SEM. Low magnification view. Note different size caryophyllidia. $\times 60$. (C) SEM. Caryophyllidia. Sensory knob with tuft of cilia placed in a calyx-like structure supported by four spicules. $\times$ 300. (D) SEM. Caryophyllidia. View into the calyx, here supported by five spicules. $\times 500$. (E) LM. Longitudinal section through the tip of a caryophyllidia. Sensory knob with cylindrical ciliated epithelium. Below the epithelium an accumulation of cell bodies. Nerve ( $\mathbf{n})$ leading towards the sensory area, $(\mathrm{s})$ spicule. $\times 510$. 

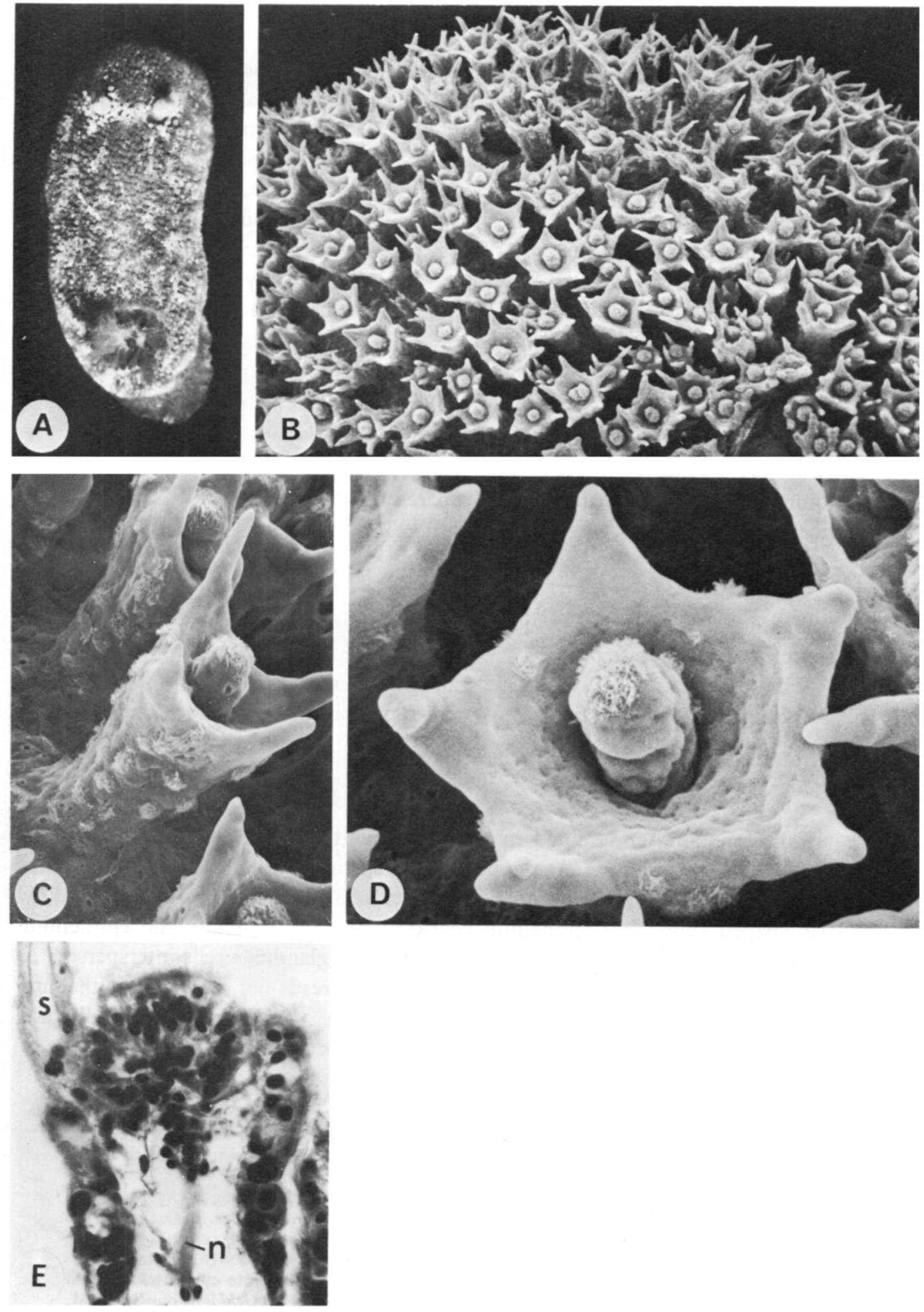


\section{$L M$}

The upper surface of the calyx and the tips of the spicules themselves are covered by a flat epithelium with occasional patches of cilia. The supporting walls of the structure are formed by a cubical epithelium having numerous ciliated cells interspersed with some glandular cells. The epithelium of the top part of the knob differs in shape; it is cylindrical, bearing long cilia and has only a few scattered glandular cells. A nerve can clearly be discerned leading to the sensory knob and spreading directly under the epithelium, forming a network there as has already been demonstrated by Labbé (1929) (Fig. 2E). Groups of cell bodies are located beneath the epithelium, probably being part of primary sensory cells. Labbé (1929, 1933) named tubercles having such sensory knobs caryophyllidia. Numerous muscle fibres are inserted at the base of the tubercles, from which it is inferred that a certain amount of movement must be possible.

\section{Macroscopical appearance}

$$
\text { Jorunna tomentosa (Cuvier, 1804) }
$$

The notum is covered with stiff spiculose tubercles, giving the animal a granular rough appearance.

\section{SEM}

The notal tubercles are caryophyllidia similar to those in Rostanga (Fig. 3A). They exhibit a circle of 6-7 spicules projecting well over the tip of the centrally located papilla (Fig. 3 B). The spicules are not connected by an epithelium as is the case in Rostanga but are free-standing. The papilla is fairly long and is topped by a knob-like structure bearing a tuft of long cilia.

\section{$L M$}

The spicules are long and rooted in the integument. They are covered by a thin epithelium without ciliated cells. At the base of the spicules are many muscle insertions which may well allow a certain amount of flexibility. The top of the papilla is covered by a regularly shaped cylindrical epithelium bearing long cilia. Laterally the epithelium becomes more cubical with fewer ciliated cells but more glandular cells interspersed. A nerve runs through the whole length of the papilla and spreads out below the epithelium at the tip as in Rostanga, as was shown by Labbé (1929, 1933) (Fig. 3E). Cell bodies are also grouped here.

Fig. 3. (A) forunna tomentosa. SEM. Low magnification view. Notum densely packed with caryophyllidia. $\times 200$. (B) Forunna tomentosa. SEM. Single tubercle showing spicules without any interconnections. Sensory papilla with a tuft of cilia on top and ciliated cells along the lateral walls. $\times 500$. (C) Onchidoris sparsa: SEM. A caryophyllidia supported by four spicules. In the centre the cauliflower-like sensory knob. $\times 500$. (D) Onchidoris sparsa. LM. Longitudinal section through the area of the sensory knob. Nerve not present in this picture, (s) spicules. $\times 1000$ (E) forunna tomentosa. LM. Longitudinal section through the tip of the sensory knob. Note cylindrical ciliated epithelium and subepithelial cell bodies. (n) Nerve, (s) spicules. $\times 370 .($ F) Ochidoris pusilla. SEM. Caryophyllidia supported by four spicules and a cauliflower-like structure in the centre, probably of sensory character. $\times 1000$. 

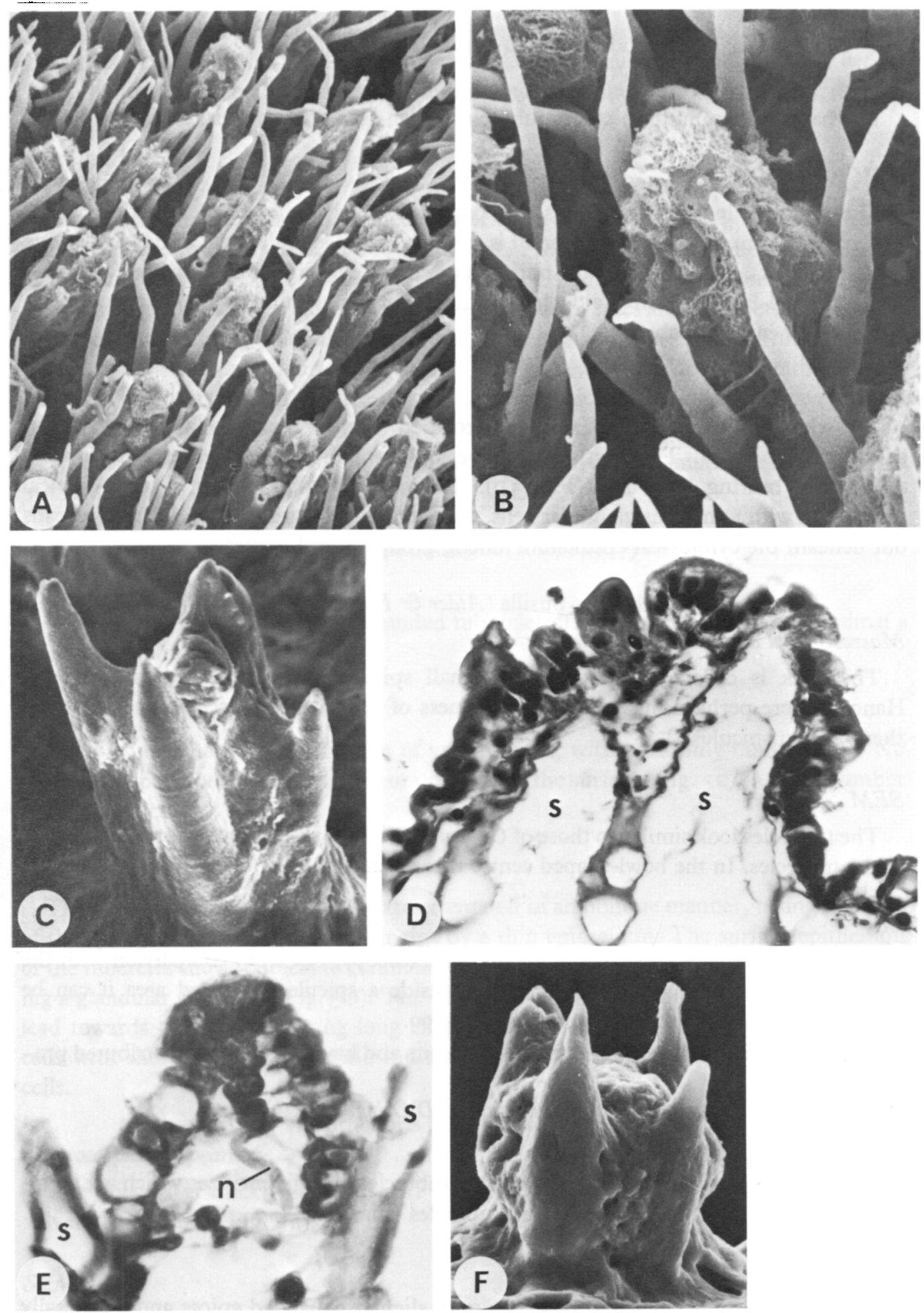


\section{Onchidoris sparsa (Alder $\mathcal{E}$ Hancock, 1846)}

\section{Macroscopical appearance}

The back bears minute spiculose tubercles which are set rather far apart.

\section{$S E M$}

The tubercles look like pyramids, the points of which are embedded in the mantle. Each of the four corners of the pyramid is supported by a spicule set at a slightly oblique angle (Fig. $3 \mathrm{C}$ ). The spicules are not connected by an epithelium but project over a shalluw, bowl-like area. In the centre of this area rests a cauliflower-like structure resembling a sensory knob.

\section{$L M$}

The whole integument is stiffened and crowded with spicules as well as the tubercles supported by them. The epithelium covering the cauliflower-like sensory knob is cylindrical, bearing long cilia (Fig. $3 \mathrm{D}$ ). The lateral surfaces show a more cubical epithelium with numerous glandular cells. A nerve leads towards the tip where it spreads out beneath the cylindrical epithelium among groups of cell bodies.

\section{Onchidoris pusilla (Alder $\&$ Hancock, 1845)}

\section{Macroscopical appearance}

The back is covered with abundant small spiculose conical tubercles. (Alder \& Hancock were perhaps misled by the smallness of the tubercles because they describe them as non spiculose.)

\section{$S E M$}

The tubercles look similar to those of O. sparsa (Fig. 3F); 4-5 spicules form the corners of the tubercles. In the bowl-shaped centre there is again a cauliflower-like structure.

\section{$L M$}

There was no material available for light microscopy, but from comparison with the other three species having a sensory knob inside a spicule-supported area it can be inferred that $O$. pusilla carries caryophyllidia too.

2. Dorids with small sensory papillae set in pits and having randomly distributed projecting spicules.

$$
\text { Aegires punctilucens (D’Orbigny, 1837) }
$$

\section{Macroscopical appearance}

The dorsum is covered with large knobbly tubercles of different sizes which are themselves invested with smaller, secondary tubercles (Fig. 4A).

\section{$S E M$}

The pictures show elongated tubercles with slightly expanded apices and a generally rounded summit (Fig. 4B). The tubercles are strengthened by numerous spicules which 
form pointed projections and which mostly correspond with the secondary tubercles. Scattered between this type of secondary tubercle are cylindrical papillae with a flat top bearing a tuft of long cilia, set in a pit and forming another type of secondary tubercle (Fig. 4C, D).

\section{$L M$}

In the paraffin sections a difference between the above-mentioned structures can be seen: the large primary tubercles are supported in the interior by spicules which elevate the epithelium on the surface and form the pointed secondary projections (Fig. 4E).

A thin single epithelium clothes the spicules. These spicules are interspersed by groups of elevated cylindrical epithelial cells, each of these structures being surrounded by a groove. These cells carry long cilia (Fig. 4F). The nerves coming up through the primary tubercles divide and end in the vicinity of cell bodies which lie underneath these epithelial cells, which have the appearance of special neurosensory ciliated cells (Fig. $4 \mathrm{~F}$ ).

3. Dorids with tubercles of different shape, invested with numerous spicules but without conspicuous sensory structures.

Archidoris pseudoargus (Rapp, 1827)

\section{Macroscopical appearance}

The dorsum is covered by low rounded tubercles of varying sizes giving the animal a warty appearance.

\section{SEM}

The pictures show blunt tubercles of various sizes, with uniformly built surface. No spicules support them on the outside or protrude at the surface (Fig. $5 \mathrm{C}$ ). A great number of cells bear cilia.

\section{$L M$}

The spicules within the tubercles are orientated in an oblique manner, taking up most of the space, and are covered at their tips by a thin epithelium. The surface epithelium of the tubercles shows cubical to columnar structure, some cells bearing cilia, others having a glandular character (Fig. 5D). The nerves visible in the tubercles divide, and most lead towards those cells bearing long cilia which are randomly distributed among the cells with shorter cilia. This could indicate that they are special neurosensory ciliated cells.

\section{Macroscopical appearance}

Acanthodoris pilosa (Müller, 1789)

The dorsum is thickly set with soft slender tapering papillae giving the animal a velvety appearance (Fig. 5A).

\section{SEM}

The papillae are long $(0.5-1 \mathrm{~mm})$ and conical, with no spicule protruding from the surface. The papillae are somewhat regularly spaced (Fig. 5B). 

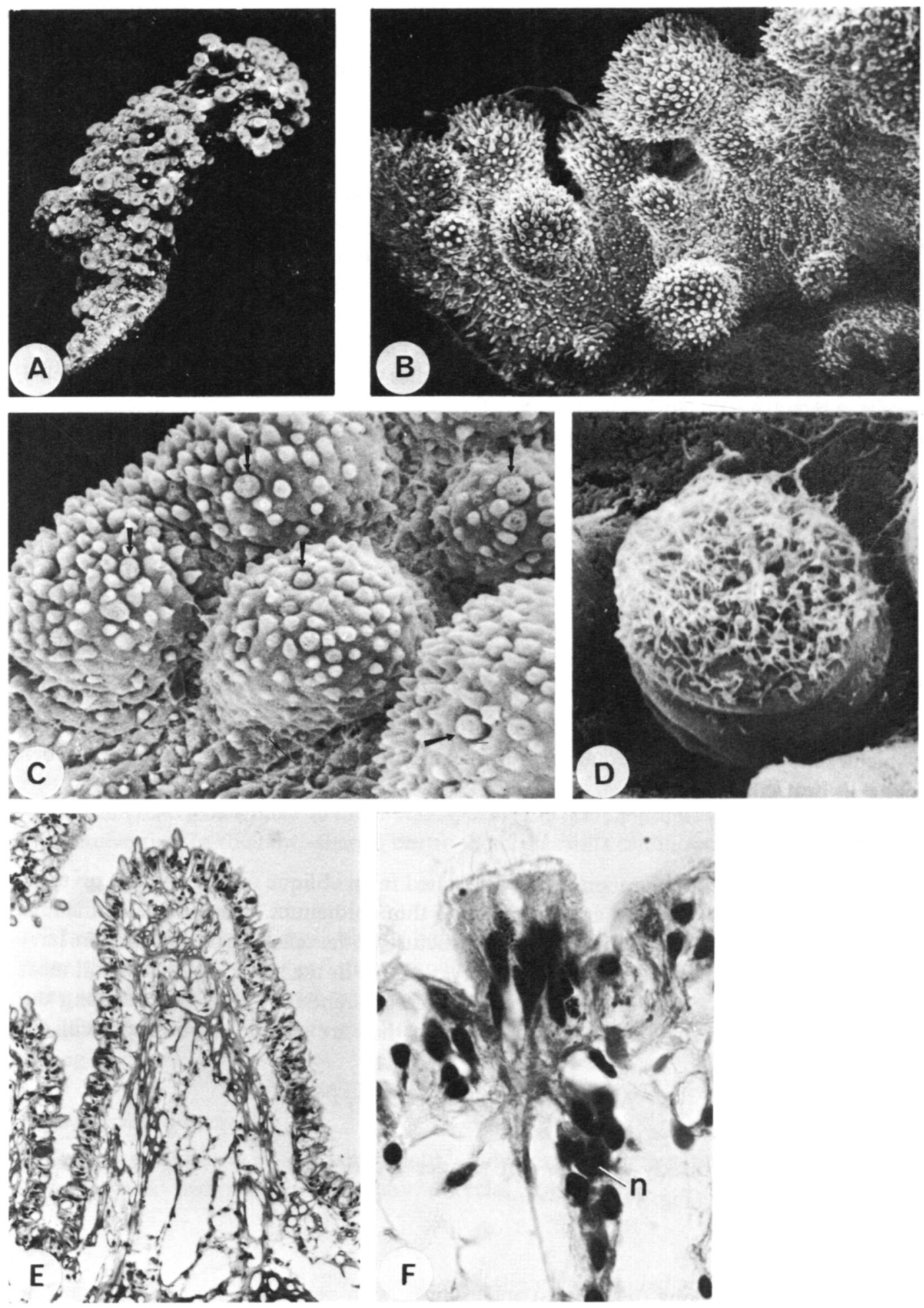


\section{$L M$}

The mantle is densely crowded with spicules but hardly any can be seen within the papillae. The surface of the tubercles is almost completely covered with cells bearing cilia of uniform length. Scattered between these are unicellular mucus cells. Nerves can be followed through the whole length of the papillae. In each case, the nerves end near the epithelium, forming a network and mingling with subepithelial cell bodies.

\section{Macroscopical appearance}

Onchidoris bilamellata $(L ., 1767)$

The mantle bears abundant strongly spiculose club-like tubercles of unequal size. The largest are placed down the sides and around the gill area, the smaller towards the margin of the mantle.

\section{$S E M$}

The pictures show stout tubercles with a slightly convex top (Fig. 6A). Depending on the diameter of the tubercle 10-15 spicules covered with epithelium project over the surface (Fig. 6C, D). They are embedded in grooves. Most of the surface is covered with cells bearing long cilia (Fig. 6B).

\section{$L M$}

The spicules inside the tubercle are thickish, blunt at the ends and bent in the centre. They slope obliquely towards the base of the tubercle. At the surface the spicules are covered with a flat epithelium while the epithelium at the top between the spicules is cylindrical in shape. A more cubical epithelium with numerous glandular cells of various types (Edmunds, 1968) occurs in the walls of the tubercles. Small nerves spread towards the epithelium at the top, but no distinct connection with a specialized area can be detected.

\section{Macroscopical appearance}

$$
\text { Onchidoris muricata (Müller, 1776) }
$$

The mantle bears numerous tall and extremely spiculose tubercles. The surface of the animal feels very rough.

\section{$S E M$}

The tubercles have a columnar shape of equal width from base to apex and are $0.2-$ $0.4 \mathrm{~mm}$ high (Fig. 5E). The top forms a flat area; 15-32 spicules set in grooves project above the surface. Most of the cells between the spicules bear cilia (Fig. 5 F).

Fig. 4. (All Aegires punctilucens.) (A) Whole animal, $10 \mathrm{~mm}$ in length. (B) SEM. Low-magnification view of the notum with the primary knobbly tubercles invested with smaller secondary tubercles. $\times 80$. (C) SEM. Primary tubercles with projecting secondary tubercles and sensory papillae set in pits (arrows). $\times$ 200. (D) SEM. A single sensory papilla set in a pit and covered with cilia on its top. $\times 2000$. (E) LM. Longitudinal section through a primary tubercle. At the surface numerous protruding spicules forming secondary tubercles. $\times 200$. (F) Section through the second kind of secondary tubercles, a sensory papilla. The epithelium consists of cylindrical cells with microvilli and long cilia. (n) Nerve and subepithelial cell bodies. $\times 1000$. 


\section{A. KRESS}
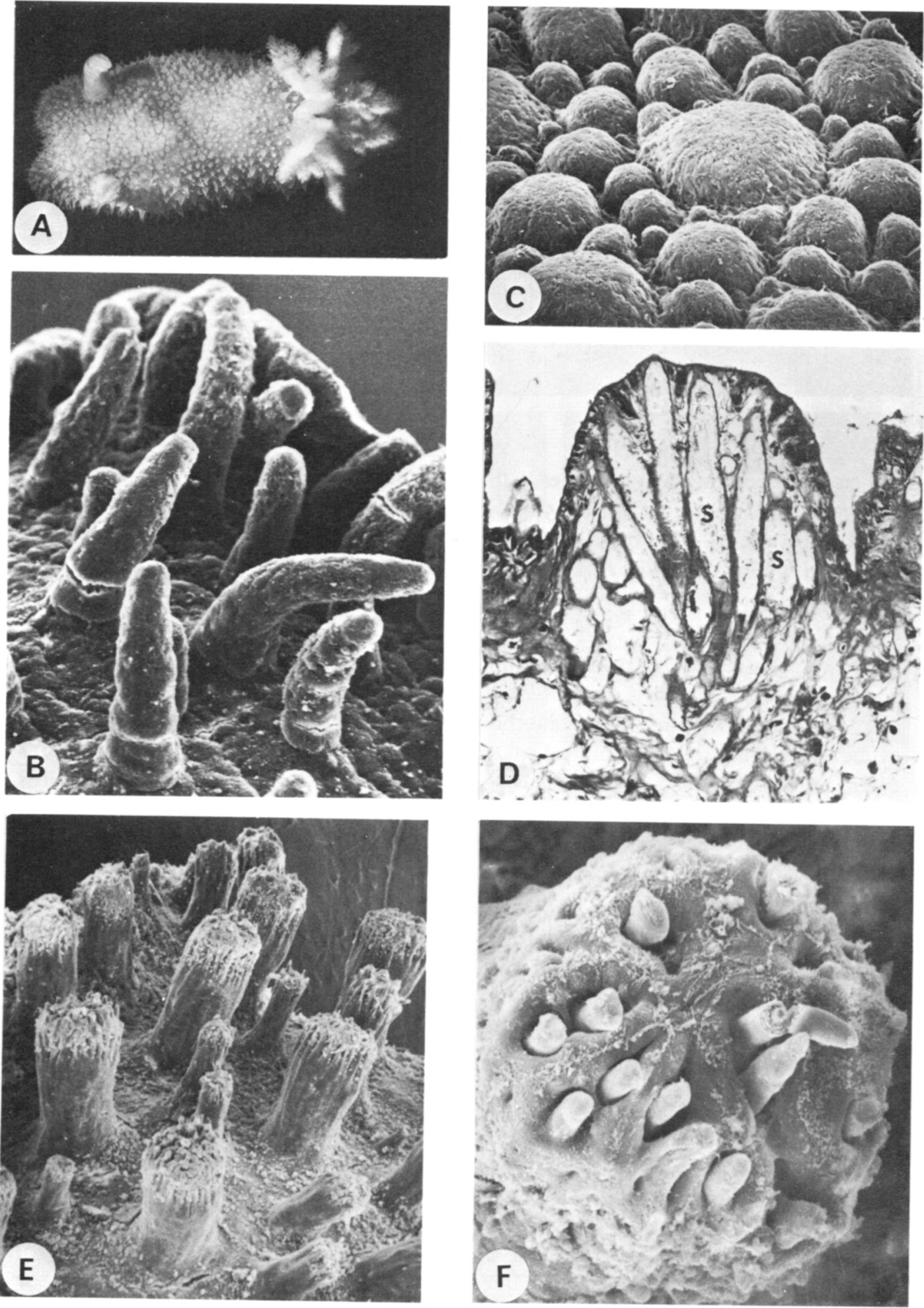


\section{$L M$}

The interior of the tubercles is crowded with spicules. The covering epithelium is cylindrical at the top and mostly ciliated, while the lateral walls exhibit more cubical epithelium and glandular cells but fewer ciliated cells. Nerves lead towards the cylindrical epithelium but no specialized area can be seen.

\section{DISCUSSION}

This study is an initial effort to describe and classify notal structures in dorid nudibranchs with SEM technique and to compare the results with light microscope sections. These notal structures are seen to vary considerably from species to species. The nine species investigated have been placed in three groups, according to the arrangement of their sensory cells within the tubercles.

1. Spicule-supported tubercles carrying a sensory knob, so called caryophyllidia. The covering of this sensory knob consists of a distinct cylindrical epithelium bearing long cilia as well as a brushborder and shows only a few glandular cells. In the interior of the knob subepithelial groups of cell bodies and a thick nerve can be seen. Labbé (1929, 1933), who described the histology of the caryophyllidia, does not mention any cilia either on the sensory knob nor along the lateral tubercle wall of Rostanga or forunna.

The dorids carrying caryophyllidia belong systematically to different families: Rostangidae, Kentrodorididae (Jorunna) and Onchidorididae. Rostanga and forunna show a close relationship apropos the structure of their tubercles, while Onchidoris sparsa and $O$. pusilla have many features in common. A systematic search would surely reveal more species with caryophyllidia in their notum as already presumed by Hoffmann (1932-34). That caryophyllidia do vary within the same genus or closely related genera has been described by Marcus (1976) in forunna and Kentrodoris. How much the variation was due to prolonged fixation and therefore possibly some dissolution of the spicules it is difficult to say.

A similar sensory structure, but not supported by spicules, has been described by Henneguy (1925) in fanolus cristatus (Antiopella). The animals carry a ruffled caruncle, a sort of sensory crest between their rhinophores, covered partly with ciliated cells and containing subpithelial nerve cells and thick nerves in the interior. According to Labbé (1933) Acanthodoris pilosa shows caryophyllidia too, but under the SEM this is seen not to be the case. Acanthodoris has slender, soft papillae without a sensory knob. Either Labbé's observation was wrong, or more probably, he confused the species.

2. Dorids with small sensory papillae set in pits as found in Aegires punctilucens. Although Labbé (1933) notes that Aegires is without any special sensory differentiations

Fig. 5. (A) Acanthodoris pilosa. Whole animal $35 \mathrm{~mm}$ in length. (B) Acanthodoris pilosa. SEM. Notal tubercles, $\times 80$. (C) Archidoris pseudoargus. SEM. Notal tubercles of various sizes. $\times 25$. (D) Archidoris pseudoargus. LM. Longitudinal section through a tubercle. The top is covered with a cylindrical epithelium interupted by spicules $(\mathrm{s}) . \times 190$. (E) Onchidoris muricata. SEM. Lowmagnification view demonstrating the high tubercles, well supported by spicules. $\times 60$. (F) Onchidoris muricata. SEM. Single tubercle showing the protruding spicules at the apical surface. One spicule has broken off. $\times 400$. 

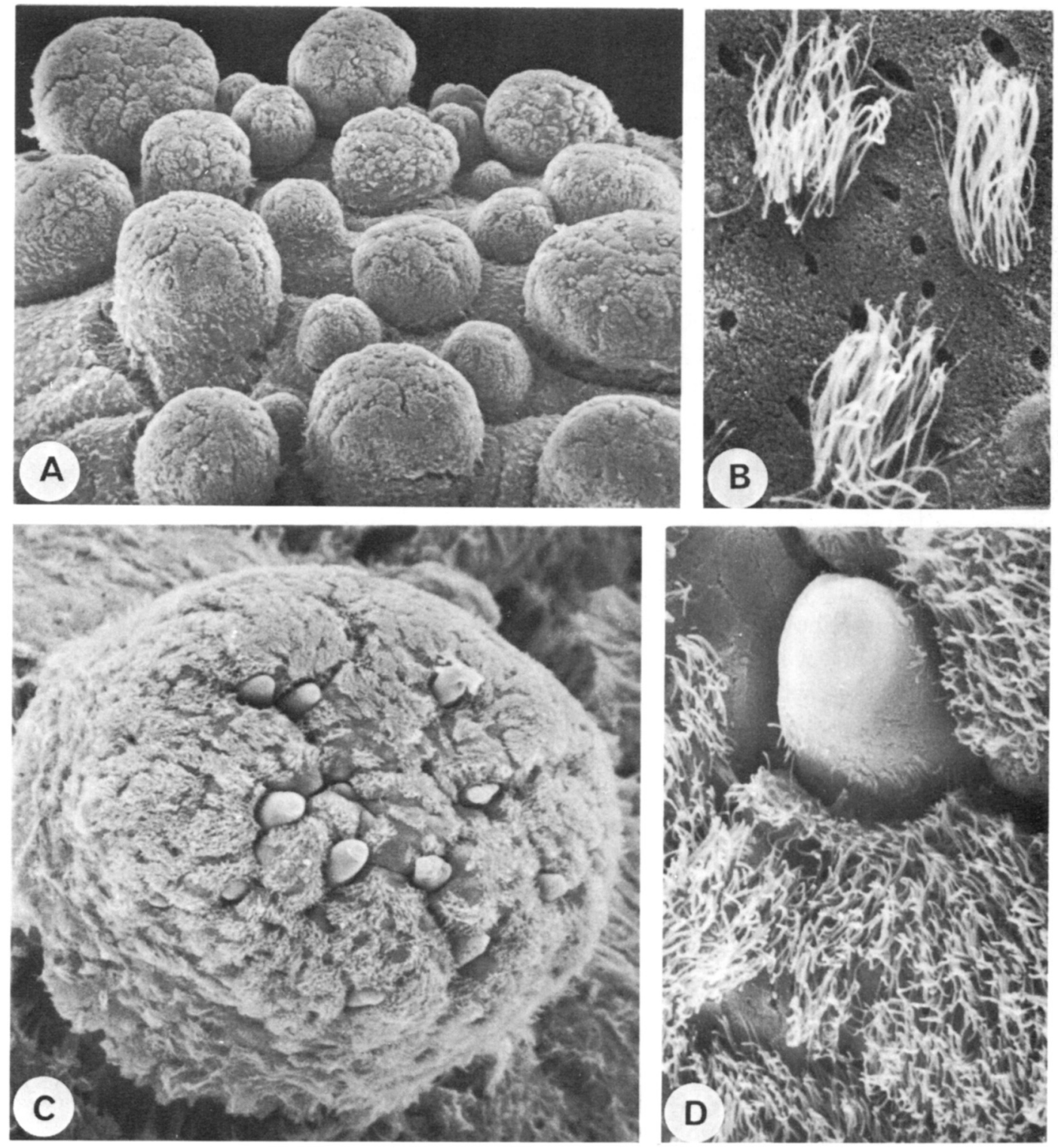

Fig. 6. (All Onchidoris bilamellata.) (A) SEM. Low-magnification view of notal tubercles of various sizes. $\times 80$. (B) SEM. Tufts of cilia in the dorsal area between the tubercles are protruding above the surrounding microvilli. The orifices of glands show clearly. $\times 2000$. (C) SEM. Single tubercle covered with ciliated cells and apically projecting spicules. $\times 300$. (D) SEM. Spicule with some single cilia at its surface. $\times 1500$.

on its notum, the SEM as well as the light microscope revealed specialized areas on the primary tubercles in the form of papillae set in pits. The covering of these papillae exhibits a ciliated cylindrical epithelium and is distinctly different from the epithelium stretched over the rest of the tubercle surface. Only below the epithelium of the ciliated papillae can groups of cell bodies and nerves be detected. 
3. All the species carrying tubercles invested with numerous spicules but without conspicuous sensory areas have been placed in the third group. Between the spicules which end directly below the covering epithelium or project over the tip, patches of a partly ciliated cylindrical epithelium can be found. Some of the ciliated cells seem to be in contact with cell bodies and thin nerves directly under the epithelium. There must presumably be some sensory regions which simply form part of the epidermis (Bullock \& Horridge, 1965; Zylstra, 1972; Navoni, 1972).

Notal tubercles have not yet been investigated on the electron microscopical level in order to differentiate the character of the sensory cells. Most authors, however, describe sensory receptor cells in molluscs as primary sensory cells with the cell bodies generally placed just below the epithelium and often associated with nerve cells (Bullock \& Horridge, 1965; Crisp, 1971; Zylstra, 1972; Wright, 1974a , $b$; Kataoka, 1976; Conklin \& Mariscal, 1977; Bonar, 1978; Emery \& Audesirk, 1978; Phillips, 1977; Jones \& Saleuddin, 1978; Owen \& McCrae, 1979). Their pictures demonstrate clearly this accumulation of cell bodies below the epithelium as found in the dorid tubercles examined above. Secondary sensory receptor cells have been described in the rhinophores of some prosobranch and opisthobranch molluscs by Storch (1971) and Storch \& Welsch (1969a, b). Their findings have not yet been fully accepted to hold true for all molluscs (Wright, $1974 b$ ). In the case of Amphioxus, however, two types of secondary sensory cells have been found (Bone \& Best, 1978).

Sensory ciliated cells may be motile but the cilia often vary from ordinary kinocilia in their interior structure or in respect to their number, location and arrangement at the cell surface as found in different molluscs by Crisp (1971), Zylstra (1972), Wright $(1974 a, b)$, Bonar (1978), Emery \& Audesirk (1978) and Jones \& Saleuddin (1978). Some ciliated sensory cells can be stiff and bristle-like as demonstrated for several molluscan species by Edmunds (1966), Crisp (1971), Conklin \& Mariscal (1977), Emery \& Audesirk (1978), Phillips (1977) and Owen \& McCrae (1979).

Microvilli are found not only at the surface of most of the covering epithelial cells forming a brush-border, but they also form part of the receptor cell surface together with one or more cilia. Microvilli responsible for registering a stimulus have been described in some pulmonate tentacle tips by Wright (1974b) and Kataoka (1976).

The functions usually assigned to superficial sensory structures in invertebrates are those of mechanoreception and chemoreception. From morphological criteria it has not been possible to distinguish receptors of the two modalities. Notal tubercles have not yet been the subject of tests as to what stimuli are received and coded.

I am grateful to the Director of the Plymouth Laboratory for providing facilities for this work; to the staff of the Laboratory, especially Dr Q. Bone and Keith Ryan for their advice and help with the SEM and J. Green (Specimen Department) for providing the living material; to Miss L. Serpell for her help with the English manuscript; and to Mrs Schaller and Mrs Zmorski for preparing the paraffin sections. 


\section{REFERENCES}

Alder, J. \& HaNCock, A., 1845-55. A Monograph of the British Nudibranchiate Mollusca. London: Ray Society.

BonaR, D. B., 1978. Ultrastructure of a cephalic sensory organ in larvae of the gastropod Phestilla sibogae (Aeolidacea, Nudibranchia). Tissue and Cell, 10, 153-165.

BONE, Q. \& BEST, A. C. G., 1978. Ciliated sensory cells in amphioxus (Branchiostoma). fournal of the Marine Biological Association of the United Kingdom, 58, 479-486.

Bullock, T. H. \& Horridge, A. G., 1965. Structure and Function in the Nervous System of Invertebrates, vols. 1 \& 2. San Francisco: W. H. Freeman \& Co.

Conklin, E. I. \& Mariscal, R. N., 1977. Feeding behavior, ceras structure, and nematocyst storage in the aeolid nudibranch, Spurilla neapolitana (Mollusca). Bulletin of Marine Science, 27, 658-667.

CRISP, M., 1971. Structure and abundance of receptors of the unspecialized external epithelium of Nassarius reticulatus [Gastropoda, Prosobranchia]. Fournal of the Marine Biological Association of the United Kingdom, 51, 865-89o.

EDMunds, M., 1966. Protective mechanisms in the Eolidacea (Mollusca, Nudibranchia). Fournal of the Linnean Society (Zoology), 46, 27-71.

Edmunds, M., 1968. Acid secretion in some species of Doridacea (Mollusca, Nudibranchia). Proceedings of the Malacological Society of London, 38, 121-133.

EMERY, D. G. \& Audesirk, T. E., 1978. Sensory cells in Aplysia. Fournal of Neurobiology, 9, 173179.

Henneguy, L. F., 1925. Contribution à l'histologie des nudibranches. Archives d'Anatomie microscopique, 21, 400-468.

Hoffmann, H., 1932-34. Opisthobranchia, Teil I. In Bronn's Klassen und Ordnungen des Tierreichs, Bd 3: Mollusca, Abt. 2: Gastropoda, Buch 3: Opisthobranchia. Leipzig.

JoNES, G. M. \& SAlEudDin, S. M., 1978. Ultrastructural observations on sensory cells and the peripheral nervous system in the mantle edge of Helisoma duryi (Mollusca: Pulmonata). Canadian Fournal of Zoology, 56, 1807-1821.

KatAOKA, S., 1976. Fine structure of the epidermis of the optic tentacle in a slug, Limax flavus $\mathrm{L}$. Tissue and Cell, 8, 47-60.

LABBÉ, A., 1929. Les organes palléaux (Caryophyllidies) et le tissu conjonctif du manteau de Rostanga coccinea Forbes. Archives d'anatomie microscopique, 25, 87-103.

LABBÉ, A., 1933. Les organes palléaux (Caryophyllidies) des Doridiens. Archives de zoologie expérimentale et générale, 75, 211-220.

MARCUS, d.B.-R. E., 1976. On Kentrodoris and Forunna (Gastropoda, Opisthobranchia). Boletim de Zoologia, Universidade de São Paulo, 1, 11-68.

MARISCAL, R. N., 1974. Scanning electron microscopy of the sensory surface of the tentacles of sea anemones and corals. Zeitschrift für Zellforschung und mikroskopische Anatomie, 147, 149156.

NavoNI, L., 1972. Der chemische Sinn der Nudibranchier (Gastropoda, Opisthobranchia). Revue suisse de zoologie, 79, 1333-1379.

OWEN, G. \& MCCRAE, J. M., 1979. Sensory cell/gland cell complexes associated with the pallial tentacles of the bivalve Lima hians (Gmelin), with a note on specialized cilia on the pallial curtains. Philosophical Transactions of the Royal Society (B), 287, 45-62.

PhILlips, D. W., 1977. A scanning electron microscope study of sensory tentacles on the mantle margin of the gastropod Acmaea (Notoacmaea) satum. Veliger, 19, 266-271.

STORCH, V., 1971. Biogene Amine in Rezeptororganen von Gastropoden (Prosobranchia, Opisthobranchia). Zeitschrift für Zellforschung und mikroskopische Anatomie, 115, 94-99.

StorCh, V. \& WeLSCH, U., 1969a. Über Aufbau und Innervation der Kopfanhänge der prosobranchen Schnecken. Zeitschrift für Zellforschung und mikroskopische Anatomie, 102, 419-431.

STORCH, V. \& WelsCH, U., 1969b. Uber Bau und Funktion der Nudibranchier-Rhinophoren. Zeitschrift für Zellforschung und mikroskopische Anatomie, 97, 528-536.

Tномpson, T. E. \& BRown, G. H., 1976. British opisthobranch molluscs. Synopses of the British Fauna, no. 8, 203 pp. 
WRIGHT, B. R., 1974a. Sensory structure of the tentacles of the slug, Arion ater (Pulmonata, Mollusca). 1. Ultrastructure of the distal epithelium, receptor cells and tentacular ganglion. Cell and Tissue Research, 151, 229-244.

WRIGHT, B. R., 1974b. Sensory structure of the tentacles of the slug Arion ater (Pulmonata, Mollusca. 2. Ultrastructure of the free nerve endings in the distal epithelium. Cell and Tissue Research, 151, 245-257.

ZYLSTRA, U., 1972. Distribution and ultrastructure of epidermal sensory cells in the freshwater snails Lymnaea stagnalis and Biomphalaria pfeifferi. Netherlands fournal of Zoology, 22, 283298. 